Jahangirnagar University J. Biol. Sci. 9(1 \& 2): 21-34, 2020 (June \& December)

\title{
Assessment of status and threats of wild mammals in some selected locations of Dinajpur district, Bangladesh
}

\author{
Md. Amdadul Haque*, M. Monirul H. Khan and Md. Mofizul Kabir \\ Department of Zoology, Jahangirnagar University, Savar, Dhaka-1342, Bangladesh
}

\begin{abstract}
The status of mammals in Dinajpur district was studied from October 2016 to November 2017. For inventory and assessment of wild mammal's belt-transect sampling, box trap survey, mist netting, night survey and questionnaire survey methods were used. A total of 22 species of mammals belonging to 11 families and 5 orders were recorded. Of the recorded species 8 were rodents, 1 hare, 1 shrew, 7 bats and 5 carnivores. Muridae appeared as the largest family containing 8 species. A total of 9 species $(41 \%)$ were recorded as "very common", 6 species (27\%) "common", 4 species (18\%) "uncommon", and 3 species (14\%) "rare". Among all the mammalian species, $41 \%$ (9 species) were nocturnal, 14\% (3 species) crepuscular, $37 \%$ (8 species) metaturnal and $9 \%$ (2 species) diurnal. On the other hand, 55\% (12 species) of mammals were terrestrial, 9\% (2 species) arboreal, 32\% (7 species) aerial and $4 \%$ ( 1 species) aquatic mammals. Of all the recorded species, $32 \%$ ( 7 species) were herbivores followed by $27 \%$ (6 species) carnivores, $5 \%$ (1 species) opportunists while frugivores and insectivores were 18\% (4 species) each. About 19\% (4 species) of the known species are nationally threatened comprising of Endangered (5\%), Vulnerable (5\%) and Near Threatened $(9 \%)$ and Least Concern $(81 \%)$. Based on the habitats, 14 species $(64 \%)$ were recorded from forests, $7(31 \%)$ from homestead vegetation's and $1(5 \%)$ species from wetlands. A good number of individuals $(\mathrm{n}=12)$ of the nationally threatened Bengal Fox (Vulpes bengalensis) were found in the study area and two mammal species, Indian Hare (Lepus nigricollis) and Large Indian Civet (Viverra zibetha) have been locally facing the threat of extirpation. The mammalian diversity in the natural forests $(64 \%)$ was higher than that of the other habitats. Different anthropogenic threats, especially hunting by ethnic Santal people (frequency of observation 24 times, impact point 4), exist in the study area. The major proposed actions for the study area are habitat restoration, increase public awareness and conflict management.
\end{abstract}

Key words: Bangladesh, Mammals, Dinajpur, Status, Threats.

\section{INTRODUCTION}

Bangladesh harbours a total of 127 species of mammals (IUCN, 2015). The presence of such a large number of species in a small hugely populated country (160 million humans in $147570 \mathrm{~km}^{2}$ ) has been possible due to its geographic position in between IndoHimalayas and Indo-China sub-regions (IUCN, 2015). The country supports roughly onefourth of the Indian mammalian species (Ahsan \& Chowdhury, 2008), 26\% of the South Asian mammalian species and $2.4 \%$ of all the mammalian species of the world (IUCN, 2015). However, the mammalian population trends clearly indicate deteriorating trend during the past several decades (Siddiqui \& Faizuddin, 1981; Islam et al., 20006). It is

\footnotetext{
* Corresponding author. E-mail: amdadulhaqueju@gmail.com
} 
possible that a falling of mammalian population further accelerated by diverse and pervasive anthropogenic threats throughout their ranges. As part of the biodiversity conservation effort, there are 47 Protected Areas (PAs) in the country of which 18 are National Parks (NPs) and 29 Wildlife Sanctuaries (WSs) (www.bforest.gov.bd), but extensive work on mammalian fauna not only in these PAs, but also in any area of Bangladesh are limited. Previously most of the works were performed on a single species of an area (Capped Langur: Islam, 1979; Kabir, 2006 and Asian Elephant: Zabed, 1992); on a specific group, e.g., bats (Ahmed, 1975; Hasan et al., 2015), primates (Ahsan, 1984; Hasan et al., 2014 ); wildlife of a specific area, e.g., National Park (Feeroz, 2003) and biodiversity on a specific area, e.g., Rema-Kalenga WS (Feeroz et al., 2011), Dudpukuria-Dhopachari WS (Feeroz et al., 2012) and Teknaf WS (Feeroz, 2013). The published and unpublished works, moreover, neither is exclusively on mammals nor on other groups of wildlife in Dinajpur area available. The goal of this study was to ensure the availability of living mammals, particularly the threatened species, in Dinajpur, Bangladesh. The objectives were: a) prepare a checklist of mammals that exist in Dinajpur; b) assess the status and habitat-wise distribution of mammals; and c) identify and assess the threats to the threatened mammals.

\section{METERIALS AND METHODS}

Study area: Dinajpur district is located between $25^{\circ} 09$ to $26^{\circ} 03 \mathrm{~N}$ and $88^{\circ} 21$ to $89^{\circ} 21 \mathrm{E}$. Thakurgaon and Panchagarh Districts in the north, Gaibandha and Joypurhat Districts in the south, Nilphamari and Rangpur Districts in the east, and the Indian state of West Bengal in the southwest. The total area of Dinajpur district is 3437.98 sq. km. Annual temperature ranges from $12^{\circ} \mathrm{C}$ to $33^{\circ} \mathrm{C}$, annual rainfall $1979 \mathrm{~mm}$, the average relative humidity $78.19 \%$ is high throughout the year, which ranges from 65 to $86 \%$ (www.timeanddate.com). Dinajpur is a plain land with no hilly areas in any parts of the district. It is about $37 \mathrm{~m}$ high from the sea level. The minor ethnic community in Dinajpur is Santal, locally known as "Shawtal". Dinajpur possess natural Sal forest. Besides this, homestead vegetation is also notable. The study was conducted in three types of habitats, viz. forests, wetlands, and homestead vegetation situated in Fulbari, Birampur, Nawabganj and Hakimpur Upazilas (sub-districts) under Dinajpur District.

Data sampling: The methods and techniques that were applied in the field were standardized to facilitate the repeatability, particularly during the reconnaissance. Thus the result is within a known level of accuracy, precision and margins of error that can be quantified, if necessary (Khan et al., 2016). All the methods that were used scientifically valid, easy to follow and have already been practiced in the protected areas of Bangladesh (Khan, 2008; Khan et al., 2016; Feeroz, 2003; Feeroz et al., 2011, 2012; Feeroz, 2013). This study was conducted for 14 months (October 2016 to November 2017). A number of methods were followed so that all types of mammals, large and small, diurnal and nocturnal, can be covered. Priority was given to the methods that do not disturb the mammals. To aid in surveying, binocular and Canon 60D camera were used. Photographic records were kept for many mammalian species and different phases of threats. All animals that were captured were released soon after capturing. Four categories 
were used to revealing the relative abundance of different species. These are - very common (76-100\% sightings), common (51-75\% sightings), uncommon (26-50\% sightings) and rare (<25\% sightings) (Khan et al., 2016). National and global status of the recorded species has been analyzed by using status assessment carried out by IUCNBangladesh (2015).

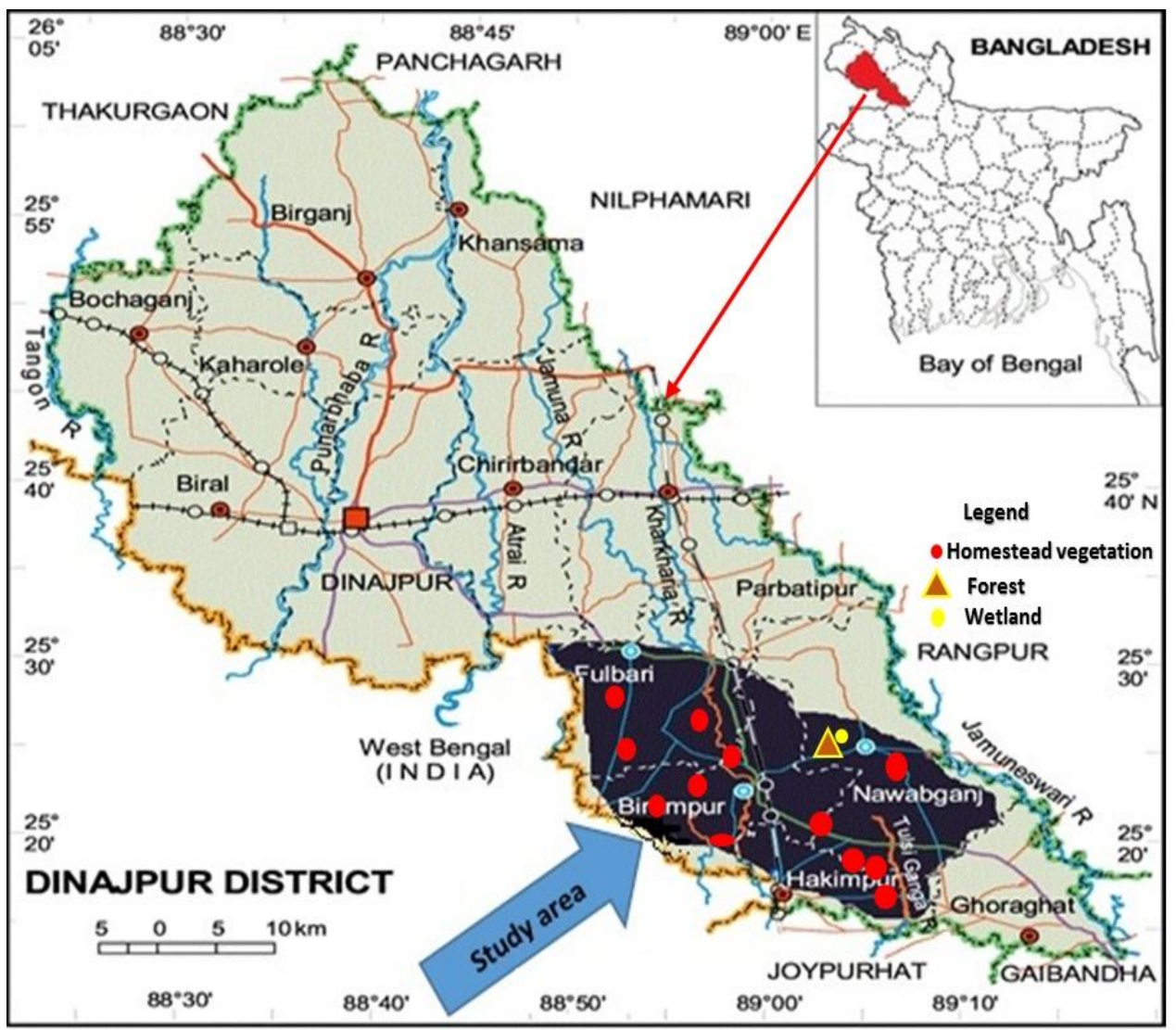

Fig. 1. Map of Dinajpur District showing different Upazilas and study area (in blue arrow)

Belt-transect sampling: Based on three type of habitats of forest, wetland and homestead vegetation in study area, nine belt transects were selected. A total of nine permanent belttransects covering a total length of $17.55 \mathrm{~km}$ (each transects more or less about $2 \mathrm{~km}$ ), were established and systematically surveyed on foot except one transect (Ashular Beel) in perennial aquatic ecosystem that was done from boat (emphasis was given in early morning and early night when wetland rats come out). Considering the visibility and accessibility in study area the fixed belt width was taken at $50 \mathrm{~m}$ and duration of observation time 8 hours per day. In belt-transect sampling the author slowly move (1.4 $\mathrm{km} / \mathrm{hr}$ ) along some relatively straight lines through the study area and recorded the animals from both sides. The survey was conducted in all seasons of the year from dawn 
$(7.00 \mathrm{am})$ to dusk $(5.30 \mathrm{pm})$ when the wild mammals remain most active. Total eight visiting trips were made at each belt transect during the study period. In transect all types of habitats were covered in order to maximize the recording of the species. Photographic records were taken for different phases of anthropogenic threats during belt transect sampling.

Box-trap survey: Small wooden and metallic wire box-traps were used, which had hide by camouflaged colors so that they could blend with the surroundings. This method was conducted for small mammals (especially rodents), which could not be covered by belt transect sampling or camera-trap survey. Medium metallic box-trap were used for medium size carnivore animals. Total six small box-traps and two medium traps were used in study area during study period. Baits were given within the triggering device and were set in apt locations. Small traps were set in forest, behind wetland and homestead vegetation but medium traps were set in forest and homestead vegetation in all seasons of the year. The box-traps were visited timely and captured animals, if any, were released very soon after recording data. Total twelve times survey was conducted at each habitat.

Mist netting: Mist netting is an efficient method of capturing flying mammals, performing this with a low risk of incidental injury. The nets were positions vertically along the flyways of local bats so that they could be sampled. Mist netting method was performed in forest and homestead vegetation along the flyways of bats during sunset when nets are not very visible. Total six times netting survey was carried out at each habitats. All species were released very soon after photographic records were taken.

Night survey: The night survey was conducted in early and late nights. This method was conducted with the help of high power torches and headlamps so nocturnal and secretive mammals, which likely to be missed in other surveys, can be observed. All types of selected habitats of nocturnal and cryptic species such as civets, cats, bats were thoroughly searched and data were recorded. A total of 30 nights were spent for night survey in selected habitats.

Questionnaire survey: It is possible that some mammals were missed in all the field surveys but these would be recorded through interview survey. This method was conducted to get the overall condition of the status of mammals in the area and the major threats to mammals. Only elderly people (who were over 40 years old) with sufficient knowledge on mammals were interviewed. Information about hunting gear, Santali name, which animal they hunt and hunting techniques were collected by interview survey. A total of 100 interview survey was conducted in different villages in different upazilas mostly on Santali people who was involved in hunting. Animal occurrence was also confirmed sporadically through interviewing local people, forest workers, farmers, fire wood collectors and elderly people to gather information about past and present status of wild mammals. Usually photograph were shown to them to confirm identification of this animal. The threats to each of the nationally threatened species of mammals were identified and assessed by direct observation in the field and by interviewing the local people. The species that listed by IUCN-Bangladesh (2015) as nationally threatened were 
considered. The basis of assessment of each of the threats was their relative frequencies of observation and interview response (Khan et al., 2016). Each of the threatened species was recorded in the field with a view to understand their nature of threats and their level of impact. Moreover, for the purpose of list and assess the anthropogenic threats, like hunting and habitat destruction, the local people were interviewed by following standard questionnaire sheets.

\section{RESULTS AND DISCUSSION}

A total of 22 species of mammal were recorded that belonged to 11 families and 5 orders, which constituted 18\% of all the species of mammal of Bangladesh (Appendix 1). Of all the mammalian species, highest number of species (i.e. 6 species) belonged to the family Muridae of the order Rodentia covering 36\% of total mammalian species. Four species were found under the family Vespertilionidae of the order Chiroptera. Two species belonged to each of the families Sciuridae of the order Rodentia, Pteropodidae of the order Chiroptera and Canidae of the order Carnivora. One species each of the families Leporidae of the order Lagomorpha, Soricidae of the order Eulipotyphla, Megadermatidae of the order Chiroptera and Felidae, Herpestidae and Viverridae of the order Carnivora were recorded. Seven species of bats, 5 species of carnivores and 8 species of rodents constituted a major part of the mammalian community in the study area.

Of all the recorded mammalian species, 9 (41\%) were "very common", 6 (27\%) "common", 4 (18\%) "uncommon" and 3 (14\%) "rare" (Figure 2). Nocturnal species were found in highest number (9) and accounted for $41 \%$ of the total 22 mammalian species. Eight $(36 \%)$ species were found to be metaturnal (sleep partly during the daytime and night) and $3(14 \%)$ species were crepuscular. $2(9 \%)$ species were diurnal. Among the mammalian species, $32 \%$ (7 species) are recorded as herbivores, in which one species i.e. Indian Hare, was under the family Leporidae of the order Lagomorpha and all the rest 6 species were under the family Muridae of the order Rodentia. The number of carnivorous mammals were 6 (27\%), frugivorous mammals $4(18 \%)$, insectivorous mammals 4 (18\%) and opportunist mammals $1(5 \%)$ (Figure 2). Among the 22 recorded mammalian species, $12(55 \%)$ species were terrestrial, $7(32 \%)$ aerial, $2(9 \%)$ arboreal and $1(4 \%)$ aquatic mammal (Figure 2).

Distribution of mammals in three types of habitats, viz. forests, homestead vegetation, and wetlands in Dinajpur have wide variety though the members of the order Carnivora were found almost uniform in both forests and homestead vegetation. Out of 22 species of recorded mammals, $14(64 \%)$ species were found in forest (NNP), $7(31 \%)$ in homestead vegetation and one $(5 \%)$ in wetland (Figure 2). No strictly, wetland dweller mammals were found in the study area. The mammalian diversity in the natural forest was higher than the other habitats (Figure 2). According to IUCN-Bangladesh (2015), 19\% of the recorded species face different categories of threats (Figure 2). Furthermore, $81 \%$ species are under the category Least Concern (not threatened). In terms of global status according to IUCN (2015), 5\% species are Near Threatened and 95\% Least Concern. 


\section{Appendix 1. Checklist of the mammals (Phylum: Chordata, Class: Mammalia) in Dinajpur}

Status: $\mathrm{VC}=$ Very Common, $\mathrm{C}=$ Common, $\mathrm{U}=$ Uncommon, $\mathrm{R}=\mathrm{Rare}$, EN= Endangered, $\mathrm{VU}=$ Vulnerable, NT $=$ Near Threatened, $\mathrm{LC}=$ Least Concern; Active Period: $\mathrm{D}=\mathrm{Diurnal}$, $\mathrm{N}=$ Nocturnal, $\mathrm{Cre}=$ Crepuscular, $\mathrm{M}=$ Metaturnal; Habitats: $\mathrm{F}=$ Forest and forest edge $\mathrm{H}=$ Homestead vegetation $\mathrm{W}=$ Wetland and surrounding; Local Name Code: $\mathrm{S}=$ Santali.

\begin{tabular}{|c|c|c|c|c|c|c|c|}
\hline \multirow[t]{2}{*}{ SI. } & \multirow[t]{2}{*}{ English name } & \multirow[t]{2}{*}{ Local name } & \multirow[t]{2}{*}{ Scientific name } & \multirow{2}{*}{$\begin{array}{l}\text { Status/Activ } \\
\text { e period }\end{array}$} & \multirow{2}{*}{$\begin{array}{l}\text { Habitat } \\
\text { used }\end{array}$} & \multicolumn{2}{|c|}{ Status } \\
\hline & & & & & & IUCN 15 & Global \\
\hline \multicolumn{8}{|c|}{$\begin{array}{l}\text { Order: Rodentia } \\
\text { Family: Muridae }\end{array}$} \\
\hline 1 & $\begin{array}{l}\text { Lesser } \\
\text { Bandicoot } \\
\text { Rat } \\
\end{array}$ & $\begin{array}{l}\text { Khet Indur, } \\
\text { Gudo (S) }\end{array}$ & $\begin{array}{l}\text { Bandicota } \\
\text { bengalensis }\end{array}$ & $\mathrm{C}, \mathrm{M}$ & $\mathrm{F}, \mathrm{H}$ & $\mathrm{LC}$ & $\mathrm{LC}$ \\
\hline 2 & $\begin{array}{l}\text { Greater } \\
\text { Bandicoot } \\
\text { Rat }\end{array}$ & $\begin{array}{l}\text { Boro Indur, } \\
\text { Gudo }(S)\end{array}$ & $\begin{array}{l}\text { Bandicota } \\
\text { indica }\end{array}$ & $\mathrm{C}, \mathrm{M}$ & $\mathrm{W}$ & LC & $\mathrm{LC}$ \\
\hline 3 & House Mouse & $\begin{array}{l}\text { Dhorea, } \\
\text { Dhere (S) }\end{array}$ & Mus musculus & $\mathrm{U}, \mathrm{M}$ & $\mathrm{H}$ & $\mathrm{LC}$ & $\mathrm{LC}$ \\
\hline 4 & Brown Rat & Geso Indur & $\begin{array}{l}\text { Rattus } \\
\text { norvegicus }\end{array}$ & $\mathrm{R}, \mathrm{M}$ & $\mathrm{H}, \mathrm{F}$ & $\mathrm{LC}$ & $\mathrm{LC}$ \\
\hline 5 & $\begin{array}{l}\text { Common } \\
\text { House Rat }\end{array}$ & $\begin{array}{l}\text { Indur, Chutia } \\
\text { (S) }\end{array}$ & Rattus rattus & $\mathrm{VC}, \mathrm{M}$ & $\mathrm{F}, \mathrm{H}$ & $\mathrm{LC}$ & $\mathrm{LC}$ \\
\hline 6 & $\begin{array}{l}\text { Asiatic Long- } \\
\text { tailed } \\
\text { Climbing } \\
\text { Mouse }\end{array}$ & $\begin{array}{l}\text { Alok } \\
\text { Dhorea, } \\
\text { Banoar (S) }\end{array}$ & $\begin{array}{l}\text { Vandeleuria } \\
\text { oleracea }\end{array}$ & VC, M & $\mathrm{F}, \mathrm{H}$ & $\mathrm{LC}$ & $\mathrm{LC}$ \\
\hline \multicolumn{8}{|c|}{ Family: Sciuridae } \\
\hline 7 & $\begin{array}{l}\text { Irrawaddy } \\
\text { Squirrel }\end{array}$ & $\begin{array}{l}\text { Lal-buk } \\
\text { Katbirali, } \\
\text { Toroi (S) }\end{array}$ & $\begin{array}{l}\text { Callosciurus } \\
\text { pygerythrus }\end{array}$ & $\mathrm{C}, \mathrm{D}$ & $\mathrm{F}$ & LC & $\mathrm{LC}$ \\
\hline 8 & $\begin{array}{l}\text { Five-striped } \\
\text { Palm Squirrel }\end{array}$ & $\begin{array}{l}\text { Dora-katha } \\
\text { Katbirali, } \\
\text { Tuor }(\mathrm{S}) \\
\end{array}$ & $\begin{array}{l}\text { Funambulus } \\
\text { pennanti }\end{array}$ & $\mathrm{C}, \mathrm{D}$ & $\mathrm{F}$ & $\mathrm{LC}$ & $\mathrm{LC}$ \\
\hline \multicolumn{8}{|c|}{$\begin{array}{l}\text { Order: Lagomorpha } \\
\text { Family; Leporidae }\end{array}$} \\
\hline 9 & Indian Hare & $\begin{array}{l}\text { Khargosh, } \\
\text { Kulai (S) }\end{array}$ & $\begin{array}{l}\text { Lepus } \\
\text { nigricollis }\end{array}$ & $\mathrm{R}, \mathrm{M}$ & $\mathrm{F}$ & EN & $\mathrm{LC}$ \\
\hline \multicolumn{8}{|c|}{$\begin{array}{l}\text { Order: Eulipotyphla } \\
\text { Family: Soricidae }\end{array}$} \\
\hline 10 & House Shrew & $\begin{array}{l}\text { Chika, } \\
\text { Chudh (S) }\end{array}$ & Suncus murinus & $\mathrm{VC}, \mathrm{N}$ & $\mathrm{F}, \mathrm{H}$ & $\mathrm{LC}$ & $\mathrm{LC}$ \\
\hline \multicolumn{8}{|c|}{$\begin{array}{l}\text { Order: Chiroptera } \\
\text { Family: Megadermatidae }\end{array}$} \\
\hline 11 & $\begin{array}{l}\text { Greater False } \\
\text { Vampire Bat }\end{array}$ & $\begin{array}{l}\text { Bhua Daini } \\
\text { Chamchika }\end{array}$ & Megaderma lyra & $\mathrm{C}, \mathrm{N}$ & $\mathrm{F}, \mathrm{H}$ & $\mathrm{LC}$ & $\mathrm{LC}$ \\
\hline \multicolumn{8}{|c|}{ Family: Pteropodidae } \\
\hline 12 & $\begin{array}{l}\text { Greater } \\
\text { Short-nosed } \\
\text { Fruit Bat } \\
\end{array}$ & $\begin{array}{l}\text { Kola Bagdor, } \\
\text { Dubak (S) }\end{array}$ & $\begin{array}{l}\text { Cynopterous } \\
\text { sphinx }\end{array}$ & $\mathrm{C}, \mathrm{N}$ & $\mathrm{H}, \mathrm{F}$ & $\mathrm{LC}$ & $\mathrm{LC}$ \\
\hline
\end{tabular}




\begin{tabular}{|c|c|c|c|c|c|c|c|}
\hline 13 & $\begin{array}{l}\text { Indian Flying } \\
\text { Fox }\end{array}$ & $\begin{array}{l}\text { Boro Badur, } \\
\text { Latu Bagdor } \\
(\mathrm{S})\end{array}$ & $\begin{array}{l}\text { Pteropus } \\
\text { giganteus }\end{array}$ & $\mathrm{VC}, \mathrm{N}$ & $\mathrm{H}, \mathrm{F}$ & $\mathrm{LC}$ & $\mathrm{LC}$ \\
\hline \multirow[t]{2}{*}{ SI. } & \multirow[t]{2}{*}{ English name } & \multirow[t]{2}{*}{ Local name } & \multirow[t]{2}{*}{ Scientific name } & \multirow{2}{*}{$\begin{array}{l}\text { Status/Activ } \\
\text { e period }\end{array}$} & \multirow{2}{*}{$\begin{array}{l}\text { Habitat } \\
\text { used }\end{array}$} & \multicolumn{2}{|c|}{ Status } \\
\hline & & & & & & IUCN 15 & Global \\
\hline \multicolumn{8}{|c|}{ Family: Vespertilionidae } \\
\hline 14 & $\begin{array}{l}\text { Indian } \\
\text { Pipistrelle }\end{array}$ & $\begin{array}{l}\text { Chamchika, } \\
\text { Kati Bagdor } \\
\text { (S) }\end{array}$ & $\begin{array}{l}\text { Pipistrellus } \\
\text { coromandra }\end{array}$ & $\mathrm{VC}, \mathrm{N}$ & $\mathrm{H}, \mathrm{F}$ & $\mathrm{LC}$ & $\mathrm{LC}$ \\
\hline 15 & $\begin{array}{l}\text { Least } \\
\text { Pipistrelle }\end{array}$ & $\begin{array}{l}\text { Soto } \\
\text { Chamchika, } \\
\text { Kati Bagdor } \\
\text { (S) }\end{array}$ & $\begin{array}{l}\text { Pipistrellus } \\
\text { tenuis }\end{array}$ & $\mathrm{R}, \mathrm{N}$ & $\mathrm{H}, \mathrm{F}$ & $\mathrm{LC}$ & $\mathrm{LC}$ \\
\hline 16 & $\begin{array}{l}\text { Common } \\
\text { Yellow Bat }\end{array}$ & $\begin{array}{l}\text { Holdey } \\
\text { Chamchika, } \\
\text { Latu } \\
\text { Chamchika } \\
\text { (S) }\end{array}$ & $\begin{array}{l}\text { Scotophilus } \\
\text { heathii }\end{array}$ & $\mathrm{VC}, \mathrm{N}$ & $\mathrm{F}, \mathrm{H}$ & $\mathrm{LC}$ & $\mathrm{LC}$ \\
\hline 17 & $\begin{array}{l}\text { Lesser } \\
\text { Asiatic } \\
\text { House Bat }\end{array}$ & $\begin{array}{l}\text { Choto } \\
\text { Holdey } \\
\text { Chamchika, } \\
\text { Kati } \\
\text { Chamchika } \\
\text { (S) } \\
\end{array}$ & $\begin{array}{l}\text { Scotophilus } \\
\text { kuhlii }\end{array}$ & $\mathrm{U}, \mathrm{N}$ & $\mathrm{F}, \mathrm{H}$ & $\mathrm{LC}$ & $\mathrm{LC}$ \\
\hline \multicolumn{8}{|c|}{$\begin{array}{l}\text { Order: Carnivora } \\
\text { Family: Canidae }\end{array}$} \\
\hline 18 & $\begin{array}{l}\text { Golden } \\
\text { Jackal }\end{array}$ & $\begin{array}{l}\text { Shial, } \\
\text { Tuyo (S) }\end{array}$ & Canis aureus & $\mathrm{VC}, \mathrm{N}$ & $\mathrm{F}, \mathrm{H}$ & $\mathrm{LC}$ & $\mathrm{LC}$ \\
\hline 19 & Bengal Fox & $\begin{array}{l}\text { Khek Shial, } \\
\text { Khikri (S) }\end{array}$ & $\begin{array}{l}\text { Vulpes } \\
\text { bengalensis }\end{array}$ & $\mathrm{UC}, \mathrm{M}$ & $\mathrm{F}, \mathrm{H}$ & VU & $\mathrm{LC}$ \\
\hline \multicolumn{8}{|c|}{ Family: Felidae } \\
\hline 20 & Jungle Cat & $\begin{array}{l}\text { Bon Biral, } \\
\text { Gaonra, } \\
\text { Runda (S), } \\
\text { Wap (S), } \\
\text { Nongor (S), } \\
\text { Unda (S) } \\
\end{array}$ & Felis chaus & VC, Cre & $\mathrm{F}, \mathrm{H}$ & NT & $\mathrm{LC}$ \\
\hline \multicolumn{8}{|c|}{ Family: Herpestidae } \\
\hline 21 & $\begin{array}{l}\text { Small Indian } \\
\text { Mongoose }\end{array}$ & $\begin{array}{l}\text { Beji, Beenji } \\
(\mathrm{S}), \text { Neul (S) }\end{array}$ & $\begin{array}{l}\text { Herpestes } \\
\text { auropunctatus }\end{array}$ & VC, Cre & $\mathrm{F}, \mathrm{H}$ & $\mathrm{LC}$ & $\mathrm{LC}$ \\
\hline \multicolumn{8}{|c|}{ Family: Viverridae } \\
\hline 22 & $\begin{array}{l}\text { Large Indian } \\
\text { Civet }\end{array}$ & $\begin{array}{l}\text { Khatash, } \\
\text { Bagdash, } \\
\text { Shogot (S), } \\
\text { Kurbag (S), } \\
\text { Bakshal (S) }\end{array}$ & Viverra zibetha & U, Cre & $\mathrm{F}, \mathrm{H}$ & NT & NT \\
\hline
\end{tabular}

The status and distribution of mammals in Dinajpur is determined by the area of different habitats, ecological requirements, natural and anthropogenic threats to habitat. The checklist presented in this paper is not a big number in comparison to the southeast, southwest and northeast part of the country. Khan et al. (2016) reported a total of 62 mammalian species from Kaptai National Park (KNP), Feeroz et al. (2012) reported a 
total of 50 mammalian species from Dudpukuria-Dhopachari Wildlife Sanctuary (DDWS), which is much more than that of the present study. The predictions for this difference are: (a) DDWS and KNP is larger than the study area; (b) DDWS and KNP is located at very remote area therefore human disturbances and hunting activity is comparatively less than the study area, and (c) intact situation of wildlife habitat in the DDWS and KNP. IUCN Bangladesh (2015) cited 49 mammalian species from Sundarbans Wildlife Sanctuary, Feeroz et al,. (2011) reported a total of 44 mammalian species from Rema-Kalenga Wildlife Sanctuary (RKWS), Aziz (2011) reported a total of 39 species of mammals from Lawachara National Park and Alam et al., (2015) reported a total of 25 mammalian species from Keshabpur, Bangladesh, which is also much more than that of the present study. However, condition of forested areas, wetland and other habitats affects the distribution of mammals in some cases. Because of plain land characteristics, less -floral diversity and canopy gap in study area makes more incompatible for arboreal mammals.

Based on the direct observation and interviewed local peoples, it can be said that three species, viz. Indian Hare (Lepus nigricollis), Irrawaddy Squirrel (Callosciurus pygerythrus) and Five-striped Palm Squirrel (Funambulus pennanti) are strictly forest dwellers during study period though local report revealed that two decades ago they were frequently found in and around human habitation. The six species found under family Muridae were relatively high in density and they are commonly seen in and around the forest, surrounding crop fields and human habitation. Chiropterans constitute a part of mammalian community here. Country's the largest fruit bat colony $( \pm 3000)$ is recorded in Birampur of Dinajpur district (Hasan et al., 2015). Seven species of bat except Flying Fox have been found in the study area from where they had been netted.

Four nationally threatened mammalian species recorded from these study sites during the study period, viz. Indian Hare (Lepus nigricollis), Bengal Fox (Vulpes bengalensis), Jungle Cat (Felis chaus) and Large Indian Civet (Viverra zibetha). A good number of individuals of Jungle Cat and Bengal Fox were recorded but Large Indian Civets and Indian Hare did not find in study area during study period though several reports (Khan, 200 and IUCN, 2015) and some forest staff who are working in forest about 20 years claimed that these two species occurred in study area. Hence, these two species evaluated as uncommon and rare. Based on field observation and interviewed local peoples, this present study claimed that this two species are locally critically endangered due to continual habitat destruction and hunting by Santal people. 


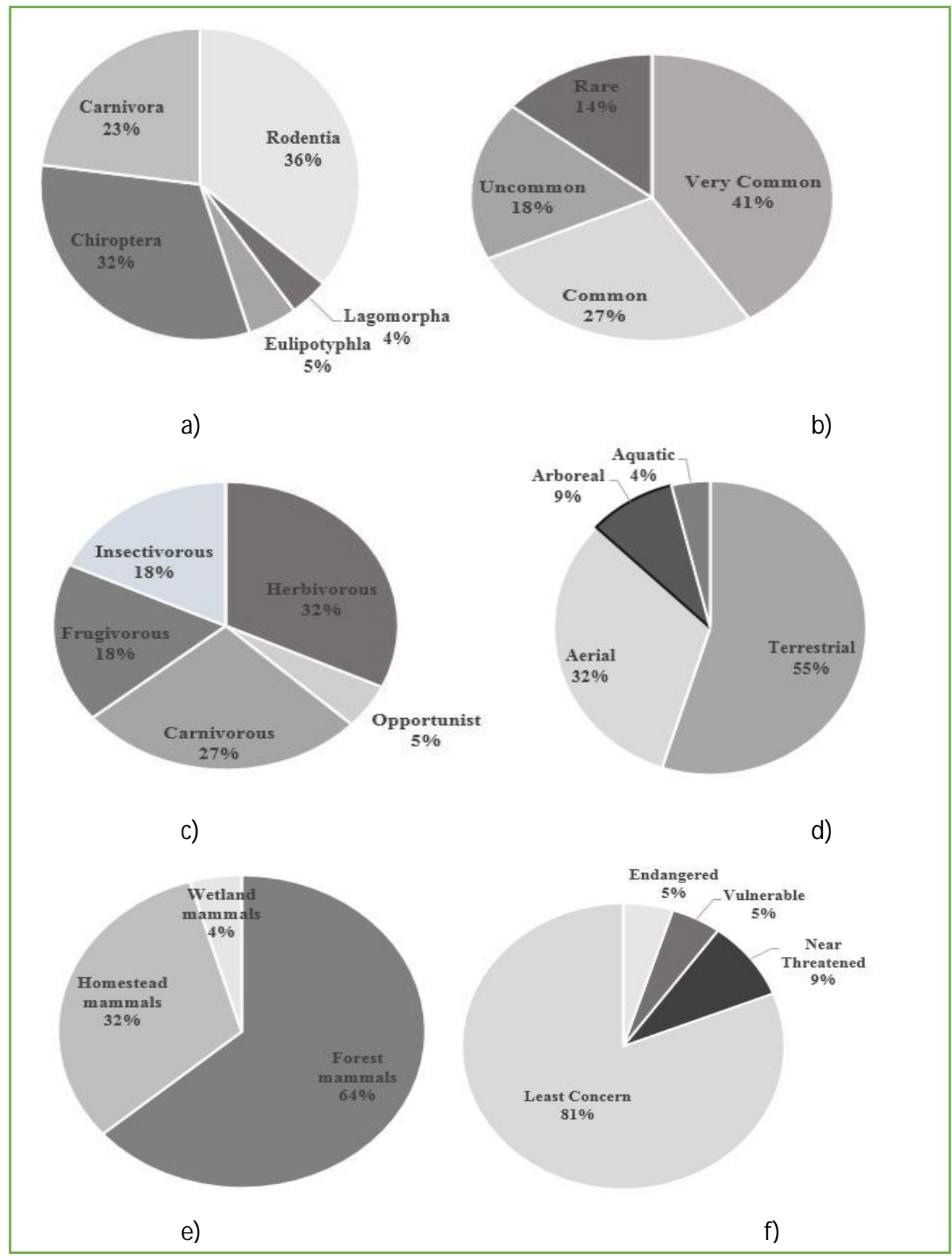

Fig. 2. Mammalian community in Dinajpur, a) Species composition, b) Relative abundance, c) Feeding groups status, d) Status of niche groups, e) Habitat distribution, f) National status 
The mammals in Dinajpur District are facing formidable threats created by people (Plate 1). Different categories of threats have different level of impact, some directly and some indirectly contributing to the decline of mammal species and populations. At least two mammal species, Indian Hare (Lepus nigricollis) and Large Indian Civet (Viverra zibetha) are facing the threat of extirpation.

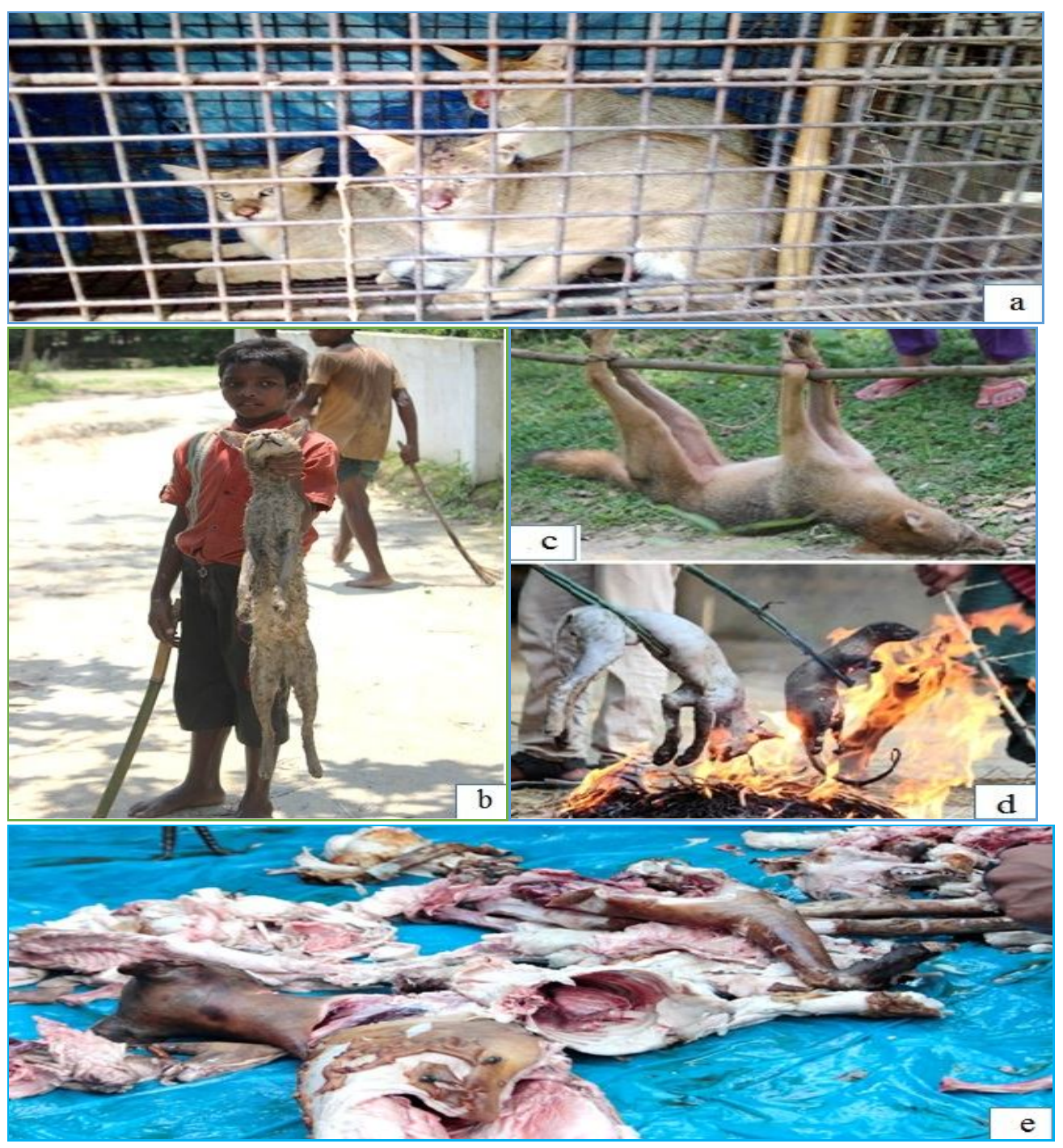

Plate 1. Threats to the mammals- a) Three Jungle Cat trapped by Santal people, b) Humanmammals conflict, c) Illegal trade (Golden Jackal for sale), d) Santal people burnt Jungle Cat (left) and Small Indian Mongoose (right) and e) Burning animal cut into pieces for distribution and cooking 
A number of threats were categorized and assessed based on their respective impacts on mammals, most of which are man-made and can be eliminated or controlled (Table 1). Special emphasis was given to the impacts on nationally threatened species (according to IUCN-Bangladesh Red List of 2015) that occur in the study area, because these are the priority species for conservation (Table 2). In general, habitat loss, degradation, fragmentation and hunting by Santal people are the major threats to mammals, which also indicated in other reports (IUCN, 2015). The Santal people living in this area hunt wild mammals throughout the year. According to Santal people interviewed, it can be said that during their hunting some animals attain high priority, viz. Small Indian Mongoose, Jungle Cat, Rodents, Flying Fox, Squirrel, Bengal Fox and Golden Jackal, etc. During the study period, the hunting activities of Santal people were witnessed for 24 times in 12 months, and different phases of hunting were photographed. The mammalian species that they commonly hunt are Jungle Cat, Mongoose, Golden Jackal, Bengal Fox, Civet, Squirrel, Hare, Flying Fox, Long-tailed Climbing Mouse, Bandicoot Rat, Brown Rat (as local Santal people report, $\mathrm{n}=28$ person), etc.

Table 1. Types of threats together with their nature and level of impacts to mammals that occur in Dinajpur district

\begin{tabular}{|c|c|c|c|}
\hline Type of Threat & Nature of Threat & $\begin{array}{c}\% \text { Frequency of } \\
\text { Observation }\end{array}$ & $\begin{array}{c}\text { Potential Impact to } \\
\text { Mammals } \\
{[1=\text { low, } 4=\text { high }]}\end{array}$ \\
\hline $\begin{array}{l}\text { Habitat loss, degradation and } \\
\text { fragmentation }\end{array}$ & Indirect & 62 & 4 \\
\hline Human-mammals conflict & Direct & 12 & 3 \\
\hline $\begin{array}{l}\text { Unintentional killing, } \\
\text { hunting, poaching }\end{array}$ & Direct & 24 & 4 \\
\hline Local trade & Direct and Indirect & 2 & 2 \\
\hline
\end{tabular}

Table 2. Threats to the nationally threatened mammals (according to IUCN Red List of 2015) that occur in Dinajpur district

\begin{tabular}{|c|c|c|c|c|c|c|}
\hline \multirow[t]{2}{*}{ Species Name } & \multirow[b]{2}{*}{$\begin{array}{c}\text { National } \\
\text { Status [EN= } \\
\text { Endangered, } \\
\text { VU }= \\
\text { Vulnerable, } \\
\text { NT }=\text { Near } \\
\text { Threatened] }\end{array}$} & \multicolumn{4}{|c|}{ Types of Threat } & \multirow[b]{2}{*}{$\begin{array}{c}\text { Level } \\
\text { of } \\
\text { Threat } \\
{[\mathrm{O}=\text { no }} \\
\text { threat, } \\
4=\text { very } \\
\text { high } \\
\text { threat }]\end{array}$} \\
\hline & & $\begin{array}{c}\text { Habitat loss, } \\
\text { degradation } \\
\text { and } \\
\text { fragmentation }\end{array}$ & $\begin{array}{c}\text { Human- } \\
\text { mammals } \\
\text { conflict }\end{array}$ & $\begin{array}{l}\text { Unintentiona } \\
1 \text { killing, } \\
\text { hunting, } \\
\text { poaching }\end{array}$ & $\begin{array}{l}\text { Local } \\
\text { trade }\end{array}$ & \\
\hline $\begin{array}{l}\text { Indian Hare } \\
\text { (Lepus nigricollis) }\end{array}$ & EN & + & - & + & + & 3 \\
\hline $\begin{array}{l}\text { Bengal Fox (Vulpes } \\
\text { bengalensis) }\end{array}$ & VU & + & + & + & + & 4 \\
\hline $\begin{array}{l}\text { Jungle Cat (Felis } \\
\text { chaus) }\end{array}$ & NT & + & + & + & + & 4 \\
\hline $\begin{array}{l}\text { Large Indian } \\
\text { Civet (Viverra } \\
\text { zibetha) }\end{array}$ & NT & + & + & + & - & 3 \\
\hline
\end{tabular}


Indiscriminate logging and habitat fragmentation are considered as major threats for the mammalian species $(21.2 \%)$ of the country (IUCN, 2015). Based on field report, collection of fuel wood and non-timber forest products, the rapid growth of canes, overgrazing by domestic animals, construction of new roads, highway, filling station, brickfield and agriculture expansion, are leading to loss, degradation and fragmentation of habitats in the study area (Table 2).

As in many other countries in the South and Southeast Asia, large areas of Bangladesh have been deforested over the past decades and mammals are the most affected group (Feeroz et al., 2013). A total of 89 species of wild animals have been reported to engage in conflict activities over the last 20 years of which 31 species are mammals (Rawshan $e t$ al., 2014). During the last two decades, the total number of human-wildlife incidents increased significantly and human's casualty during conflict also increased significantly (Rawshan et al., 2014). In study area, local peoples report available that Jungle Cat, Golden Jackal, Mongoose and Bengal Fox invade human settlement for local poultry and goat, among bats specially Flying Fox coming in human settlement for sweet fruits. As a result, competition for resources used by both the group in study area eventually creates conflict. These types of threats directly affect mammals and exert relatively high impact (Table 2).

Hunting by Santal people also ranked the highest potential threat, because it has direct impact on mammals. The Santal people hunt wild mammals mainly for meat and partially for medicinal use. The Santal hunting group consists of 8-15 members, but the number can be more or less than this. They travel through forest, villages, cultivable lands and bushy areas. If they noticed animal some members of the hunting group surround this area and chase the animal while others get ready with arms to attack the animal. They used to share the hunted animals among the group members. Santal hunt most of the animal but some animals attain high priority. For hunting, they use arrow, bow, gulati (catapult), net, stick, box trap and lancet as a hunting instrument during their hunting (as Santal people report).

Eighteen mammalian species are traded illegally according to the Wildlife Crime Control Unit (WCCU) of the Forest Department (IUCN Bangladesh, 2015). Illegal trade is considered one of the major threats for $26.5 \%$ of the mammalian species of the country (IUCN 2015). At present study it was found that, Santal people not only hunt animals for their consumption but also do local trading. Based on the interviewed local peoples, it can be said that they sell hunted animals to the Chinese and Korean people who are working in Boropukuria Coal Mine, Phulbari, Dinajpur. The hunted animals have great demand to foreign people those who are working in study area such as-Jackal/Bengal fox were sold in 1500-2500tk (=19-31 USD) and Mongoose were sold in 200-300tk (=2.5-3.75 USD) per piece (as local peoples view, $\mathrm{n}=21$ person).

In conclusion, the study is not exhaustive and could be used as a baseline to contribute in future management plan in Dinajpur area. This area still has a lot of potential, but management actions need to be taken urgently due to the area is getting poorer every day 
due to various pressures on the land and the natural resource. The proposed actions for the study area include - habitat restoration, forest department's capacity building, regular monitoring and research, ecotourism development, providing alternates of firewood, extensive social forestry, activation of co-management bodies, socio-economic development activities, institutional development, protected area management and public awareness and conflict management (educate people through workshops, film screenings, photographic displays, folk songs and staged drama events at regular intervals by govt. and NGOs).

Acknowledgements: The author thanks many anonymous reviewer for reviewing the manuscript and necessary corrections. The authors are also grateful to Anik Saha, Rony, Seefat and Galib for their assistance during the study. The authors are also very grateful to local people as well as the forest personnel for their collaboration during fieldwork.

\section{REFERENCES}

Ahmed, S.K. 1975. Bats of Bangladesh (with notes on field observations). M. Sc. Thesis (unpublished), Dhaka: Dhaka University, 92pp.

Ahsan, M.F. 1984. Study of Primates in Bangladesh: Determination of Population Status and Distribution of Non-Human Primates in Bangladesh with Emphasis on Rhesus Monkey. M. Phil. Thesis, Dhaka: Dhaka University, 162pp.

Ahsan, M.F. and Chowdhury, M.A.W. 2008. Mammals of the Chittagong University Campus, Chittagong. Bangladesh J. Zool, 36, 131-147.

Feeroz, M.M. 2003. Wildlife Diversity in Satchari Forest of North-Eastern Region of Bangladesh. Bangladesh Journal of Life Science, 15, 61-76.

Feeroz, M.M., Hasan, M.K. and Khan, M.M.H. 2011. Biodiversity of Protected Areas of Bangladesh, Vol. 1: Rema- Kalenga Wildlife Sanctuary. Dhaka: BioTrack Arannayk Foundation, 214pp.

Feeroz, M.M., Hasan, M.K. and Hossain, M.K. 2012. Biodiversity of Protected Areas of Bangladesh, Vol. 2: Dudpukuria- Dhopachari Wildlife Sanctuary. Dhaka: BioTrack Arannayk Foundation, 224pp.

Feeroz, M.M. (Ed.). 2013. Biodiversity of Protected Areas of Bangladesh, Vol. 3: Teknaf Wildlife Sanctuary. Dhaka: BioTrack Arannayk Foundation, 240pp.

Hasan, M.K., Feeroz, M.M., Jones-Engel, L., Engel, G.A., Smith, D.G. 2014. Diversity and molecular phylogeny of Rhesus macaques (Macaca mulatta) of Bangladesh. Am $J$ Primatol. 76:1074-1104.

Hasan, M.K. 2015. Mammal management strategy with emphasis on human-wildlife conflicts in Bangladesh. Bangladesh Forest Department. Prepared under the technical assistance services of Strengthening Regional Cooperation for Wildlife Protection Project (SRCWP) and implemented by Agriconsulting S.P.A. (ITA), Agrer S.A. (BE) and SODEV Consult (BD), $211 \mathrm{pp}$.

Islam, M.A. 1979. Studies on the Ecology and Population of Capped Langur, Presbytis pileatus (Blyth) of the Madhupur National Park. M.Sc. Thesis, Dhaka: Dhaka University, 96pp.

Islam, M.A., Feeroz, M.M. Muzaffar, S.B.. Kabir, M.M and Begum. S. 2006. Conservation of The Hoolock Gibbons (Hoolock hoolock) of Bangladesh: population estimates, habitat suitability and management options. Technical Report, U.S. Fish and Wildlife Service, 48 pp. 
IUCN-Bangladesh. 2015. Red List of Bangladesh Volume 2: Mammals. IUCN, International Union for Conservation of Nature, Bangladesh Country Office, Dhaka, Bangladesh, pp. $\mathrm{xvi}+232$.

Kabir, M.M. 2006. Activity pattern of capped langur in the semi-evergreen forest of Bangladesh. Bangladesh. J. life sci. 15(2): 49-58.

Khan, M.M.H. 2008. Protected Areas of Bangladesh - A guide to Wildlife, Nishorgo Program, Bangladesh Forest Department, Dhaka, Bangladesh, 304pp.

Khan, M.M.H., Begum, S., Feeroz, M.M., Kabir, M.M., Hasan, M.K., Khan, B., Rahman, T., Prodhan, M.M.H., Khan, M.N.S., Khaledin, S. and Basak, R. 2016. Wildlife of Kaptai National Park of Bangladesh. Bangladesh Forest Department, Dhaka, Bangladesh. 108 pp.

Rawshan, K., Feeroz, M.M. and Hasan, M.K. 2012. Human-carnivore conflicts in Bangladesh.Tigerpaper 39 (3):17-21.

Siddiqui, N.A. and M. Faizuddin. 1981. Distribution and population status of some mammals in Bangladesh. Bano Biggyan Patrika 10:1-6.

Zabed, A.A. 1992. An Ecological Study of Elephants Elephas maximus in the Chunati Wildlife Sanctuary. Unpublished M. Sc. Thesis, Savar: Jahangirnagar University, 102pp. 